\title{
Fermentasi Tahu Susu Sapi Yang Disubtitusi Sebagian Dengan Tahu Kedelai
}

\section{Fermentation of Cow Milk Tofu Partly Substituted With Soybean Tofu}

\author{
Mariani Haji Mansyur \\ Program Studi Teknologi Pertanian, Universitas Cokroaminoto Makassar \\ Jl. Perintis Kemerdekaan, Km. 7 Makassar \\ mariani.mansyur@gmail.com
}

\begin{abstract}
Abstrak
Tahu susu dibuat dengan cara memanaskan susu segar dengan menambahkan getah pepaya. Untuk mendapatkan cita rasa yang berbeda dari tahu susu konvensional dilakukan modifikasi pada proses pembuatan tahu susu dengan cara fermentasi dan disubtitusi tahu kedelai. Penelitian ini bertujuan untuk mengetahui proses pembuatan fermentasi tahu susu yang disubtitusi sebagian dengan tahu kedelai. Penelitian ini menggunakan Rancangan Acak Lengkap Faktorial dengan perlakuan tahu susu sapi $85 \%$ : tahu kedelai $15 \%$, tahu susu sapi $80 \%$ : tahu kedelai $20 \%$, tahu susu sapi $75 \%$ : tahu kedelai $25 \%$ dan difermentasi dengan penambahan Lactobacillus lactis sebanyak $2 \%$ dan disimpan selama 3 minggu dan setiap minggunya dilakukan pengamatan. Hasil penelitian menunjukkan bahwa tahu kedelai dan proses fermentasi berpengaruh terhadap kekenyalan dan uji organeleptik tahu susu sapi yang dihasilkan.
\end{abstract}

Kata Kunci : fermentasi; subtitusi; tahu susu; tahu kedelai

\begin{abstract}
Tofu milk is made by heating fresh milk by adding a papaya sap. To get a different taste from conventional milk tofu, modifications were made to the process of making tofu milk by fermentation and substituted by soybean tofu. This study aims to determine the process of making tofu fermented milk partially substituted with soybean tofu. This study used a Factorial Complete Randomized Design with $85 \%$ tofu milk tofu treatment: $15 \%$ soy tofu, $80 \%$ soy tofu: $20 \%$ soy tofu, $75 \%$ tofu milk: $25 \%$ soy tofu and fermented with the addition of $2 \%$ Lactobacillus lactis and kept for 3 weeks and observed every week. The results showed that soybean tofu and the fermentation process affected the elasticity and organoleptic test of tofu milk produced.
\end{abstract}

Keywords: fermentation; substitution; soybean tofu; tofu milk

\section{PENDAHULUAN}

Susu merupakan bahan pangan yang mengandung nutrisi lengkap dan cukup untuk memenuhi kebutuhan gizi manusia. Berbagai produk olahan berbahan baku susu telah dikembangkan di Indonesia sebagai sumber pangan yang menyehatkan, di antaranya dadih (Sri Usmiati dan Risfaheri, 2012). Diversifikasi atau penganekaragaman produk susu selain sebagai upaya dalam meningkatkan konsumsi gizi masyarakat dengan daya tarik keragaman produknya, juga bertujuan 
untuk meningkatkan daya tahan produk sehingga dapat mengatasi masalah keterbatasan ruang dan waktu. Dangke adalah salah satu produk tradisional yang berasal dari Kabupaten Enrekang yang merupakan bentuk diversifikasi produk olahan susu. Produk ini sangat disenangi dan diminati oleh masyarakat khususnya di kabupaten Enrekang (Fitrah, 2012). Produk olahan susu ini memiliki nilai gizi yang tinggi (Marzoeki, 2003).

Pembuatan dangke dilakukan dengan memanaskan susu yang masih baik serta menggunakan api kecil sampai mendidih (suhu pasteurisasi/di bawah suhu $100^{\circ} \mathrm{C}$ ), kemudian ditambahkan bahan penggumpal/getah pepaya sehingga terbentuk gumpalan. Getah pepaya yang ditambahkan mengandung enzim papain (Malaka et al, 2015). Enzim papain salah satu jenis enzim protease yang dapat mengkoagulasikan misel kasein yang ada dalam susu (Geantaresa dan Supriyanti, 2010). Aktivitas papain cukup spesifik karena papain hanya dapat mengkatalisis proses hidrolisis dengan baik pada kondisi $\mathrm{pH}$ serta suhu dalam kisaran waktu tertentu. Papain mempunyai kondisi $\mathrm{pH} \mathrm{5,0} \mathrm{-} \mathrm{7,0,} \mathrm{tetapi} \mathrm{untuk} \mathrm{pH}$ optimumnya tergantung pada substrat (Muchtadi, et al., 1992). Suhu optimal papain menurut Winarno (1995) adalah 50-60 $\mathrm{C}$ sedangkan menurut Ming et al (2002) suhu optimal papain sekitar $60^{\circ} \mathrm{C}$. Kelebihan papain dibandingkan proteolitik yang lain adalah lebih tahan terhadap suhu proses, mempunyai kisaran $\mathrm{pH}$ yang luas dan lebih murni dibandingkan bromelin dan ficin.

Dangke atau tahu yang digumpalkan dengan getah pepaya memiliki sifat fisik berwarna putih, tekstur keras (padat) dan elastis, cita rasa dan aromanya khas susu dan tidak pahit Mustikawati (2001) . Menurut Marsoeki (2003) bahwa dangke asli dapat dibedakan dengan dangke yang telah dicampur dengan tepung atau dipalsukan antara lain : dangke asli elastis dan berwarna putih sedangkan dangke campuran tidak elastis dan warnanya agak kekuningan. Selama ini pembuatan tahu susu tidak banyak berubah dari segi teknis maupun hasil akhir (cita rasa). Untuk mendapatkan cita rasa yang berbeda dari tahu susu konvensional dilakukan modifikasi terhadap proses pembuatan tahu susu dengan penambahan tahu kedelai dan difermentasi dengan menggunakan Lactobacillus lactis. Penambahan tahu kedelai diharapkan dapat memperbaiki cita rasa dan sifat fisik dari tahu suhu yang dihasilkan.

\section{METODOLOGI}

Alat yang digunakan dalam penelitian ini adalah timbangan analitik, panci, batang pengaduk, tabung reaksi, incubator, shaker incubator, jarum ose, thermometer, karet pengisap, pipet tetes, Erlenmeyer, alat penangas, blender, gelas piala, baskom, gelas, mikser, autoclave, kain kasa, sendok, kompor, lemari es, cetakan tahu susu, kain saring. Sedangkan bahan yang digunakan dalam penelitian ini adalah aquadest, aluminium foil, kapas, media MRS, susu skim, susu sapi, cuka, kedelai, getah papaya, air, dan garam.

Penelitian ini menggunakan rancangan acak lengak factorial dengan membuat tahu susu yang dimodifikasi dengan tahu kedelai dengan perlakuan 1 tahu susu sapi $85 \%$ : tahu kedelai $15 \%$, perlakuan 2 tahu susu sapi $80 \%$ : tahu kedelai $20 \%$, perlakuan 3 tahu susu sapi $75 \%$ : tahu kedelai $25 \%$ dan difermatsi dengan penambahan Lactobacillus lactis sebanyak $2 \%$ dan disimpan selama 3 minggu. Adapun prosedur kerja penelitian ini yaitu 


\section{Pembuatan Stater Culture Lactobacillus lactis}

Media MRS ditimbang sebanyak 5,2 gram dan media agar 2,5 gram kemudian media tersebut dimasukkan kedalam Erlenmeyer dan ditambahkan aquadest sebanyak $100 \mathrm{ml}$. Dipanaskan pada penangas hingga mendidih kemudian dituang pada tabung reaksi lalu ditutup dengan kapas dan aluminium foil. Media tersebut kemudian disterilkan dalam autoclave selama 15 menit dengan suhu $121^{\circ} \mathrm{C}$ lalu disimpan dalam lemari es dengan posisi miring (media padat). Penanaman mikroba (Lactobacillus lactis)

Susu skim ditimbang sebanyak 25 gram kemudian dituang dalam Erlenmeyer dan tambahkan susu sapi menjadi $100 \mathrm{ml}$ lalu diaduk hingga homogen. Larutan tadi kemudian dipasteurisasi selama 15 menit dengan suhu $80^{\circ} \mathrm{C}$. ditambahkan Lactobacillus lactis sebanyak 10 ose kemudian diinkubasi dalam shaker incubator selama 24 jam.

\section{Pembuatan Larutan Getah Papaya}

Buah papaya yang masih muda atau masih bergetah dibersihkan sebelum ditoreh menggunakan kapas yang diberi alcohol 70\%. Kulit buah ditoreh dibeberapa bagian permukaan kulit buah dengan arah membujur dari bagian atas ke bawah yang tetesan getah ditampung pada wadah. Sebanyak 5 gram getah kemudian diencerkan dengan air suling menjadi $100 \mathrm{ml}$ sambal diaduk selama kurang lebih 5 menit. Larutan getah didiamkan selama 15 menit kemudian disaring dengan kain saring untuk memisahkan endapan getah dengan larutan getah papaya. Larutan getah papaya siap digunakan.

\section{Penggumpalan Susu Sapi}

Satu liter susu sapi yang telah disaring terlebih dahulu dipanaskan dengan suhu $80^{\circ} \mathrm{C}$. setelah mendidih dilakukan penambahan getah papaya sedikit demi sedikit sebanyak $2 \mathrm{ml}$ sampai terbentuk gumpalan-gumpalan. Gumpalan-gumpalan tersebut kemudian dipisahkan dari whey dengan menggunakan kain saring atau saringan bulat yang biasa digunakan untuk menyaring sehingga terbentuk tahu susu.

\section{Pembuatan Tahu Kedelai}

Kedelai yang telah disortasi kemudian dicuci bersih kemudian direndam selama 3 jam lalu dipanaskan selama 5 menit untuk mempermudah pengelupasan kulit ari. Digiling dengan perbandingan 1:6 (kedelai:air) dengan menggunakan air panas. dididihkan, yang bertujuan menghilangkan bau langu, mempermudah ekstraksi dan membunuh mikroba yang ada. Disaring untuk memisahkan antara ampas dan susu kedelai. Satu liter susu kedelai kemudian digumpalkan dengan meanambahkan larutan cuka sebanyak $2 \mathrm{ml}$ selama 30 menit kemudian dilakukan penyaringan untuk memisahkan antara gumpalan (curd) protein kedelai dengan whey. Gumpalan kemudian dicetak dengan menggunakan cetakan sederhana dan dilanjutkan dengan proses pengepresan sehingga terbentuk produk tahu kedelai.

\section{Pembuatan Tahu Susu Fermentasi}

Penggabungan antara gumpalan susu dan tahu kedelai dilakukan sesuai perlakuan. Perlakuan 1 Tahu susu sapi 85\% : Tahu susu kedelai 15\%, Perlakuan 2 
Tahu susu sapi $80 \%$ : Tahu susu kedelai 20\%, Perlakuan 3 Tahu susu sapi $75 \%$ : Tahu susu kedelai 25\%. Penambahan starter (Lactobacillus lactis) 2\% pada masingmasing perlakuan kemudian diaduk menggunakan mikser hingga homogen dengan kecepatan rendah. Dicetak kemudian diinkubasi selama 48 jam pada suhu ruang (difermentasi). Dilakukan penyimpanan (1 minggu, 2 minggu, dan 3 minggu).

Hasil tahu susu modifikasi diamati dengan uji fisik yaitu tingkat kekenyalan dengan menggunakan alat texture analyzer dan uji organoleptic yang dilakukan meliputi tekstur, aroma,warna dan rasa, dari tahu susu fermentasi yang disajikan. Metode pengujian yang dilakukan adalah metode hedonic (uji kesukaan). Skor yang digunakan adalah (5) sangat suka, (4) suka, (3) agak suka, (2) tidak suka (1) sangat tidak suka

\section{HASIL DAN PEMBAHASAN}

\section{Uji Fisik (Kekenyalan Tekstur)}

Uji kekenyalan/tektur ini bertujuan untuk mengetahui tingkat kekenyalan fermentasi tahu susu yang dihasilkan selama penyimpanan pada semua perlakuan dengan menggunakan alat Textur Analyzer. Hasil tersebut dapat dilihat pada gambar berikut :

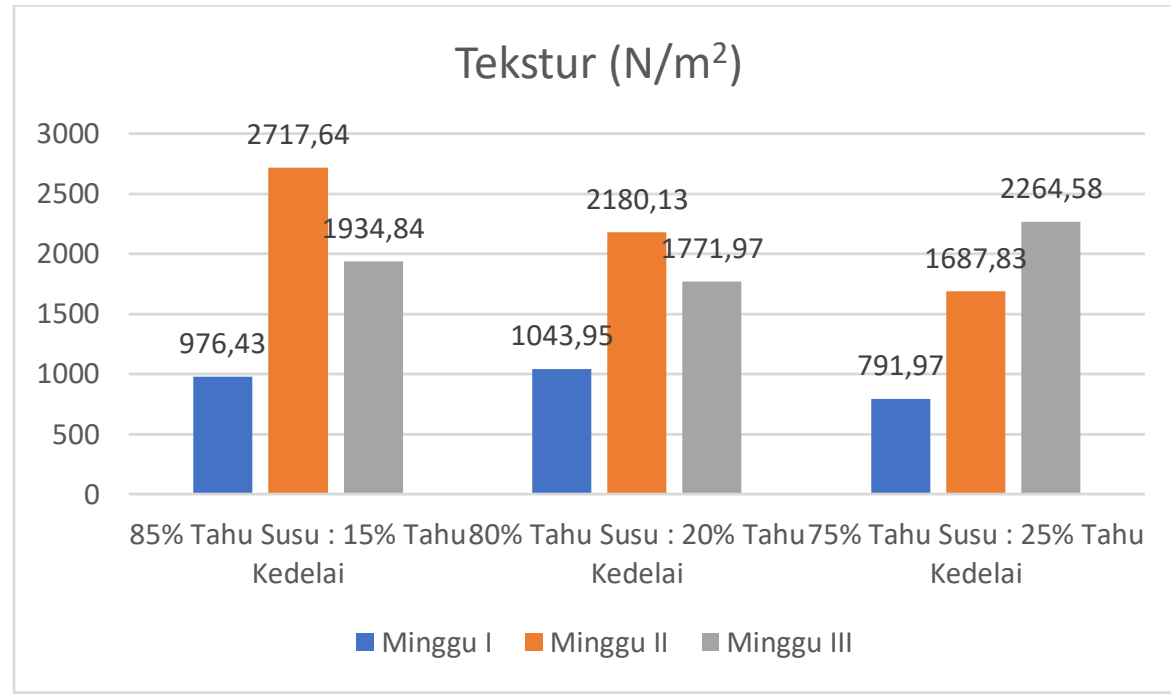

Gambar 1. Tekstur/ Kekenyalan $\left(\mathrm{N} / \mathrm{m}^{2}\right)$ Tahu Susu Fermentasi

Berdasarkan gambar 1 dapat dilihat bahwa hasil uji kekenyalan menggunakan alat textur analyzer pad tahu yang difermentasi menunjukkan tingkat kekenyalan tertinggi yaitu pada perlakuan $85 \%: 15 \%$ (tahu susu sapi : tahu kedelai) yang disimpan selama 2 minggu dengan nilai $2717 \mathrm{~N} / \mathrm{m}^{2}$, sedangkan tingkat kekenyalan terendah yaitu pada perlakuan $75 \%: 25 \%$ (tahu susu sapi : tahu kedelai) yang disimpan selama 1 minggu $791,975 \mathrm{~N} / \mathrm{m}^{2}$. Hal ini dikarenakan adanya penambahan tahu kedelai, dimana antara protein tahu susu sapi dengan tahu kedelai memiliki sifat dan kekenyalan tidak sama. Hal ini sesuai pendapat (Winarno,1995) bahwa kekenyalan tahu susu terlihat bahwa semakin tinggi dosis enzim yang digunakan maka akan dihasilkan tahu susu yang semakin kenyal. Salah satu sifat dari enzim papain adalah mempunyai keaktifan sintetik yaitu kemampuan membentuk protein baru yang disebut palestin yang akan mempengaruhi kekenyalan sehingga semakin tinggi level pemberian enzim papain dalam 
pembuatan tahu susu akan meningkatkan pembentukkan palestin dengan demikian meningkatnya palestin maka tahu susu yang dihasilkan akan semakin kenyal. Semakin lama perendaman maka kadar protein semakin menurun sedangkan kadar air semakin meningkat (Sarwono dan Saragih, 2001). Tahu kedelai dengan kandungan air yang tinggi akan memberikan penampakan yang lembut, sebaliknya tahu dengan kadar air yang rendah akan memberikan penampakan tekstur yang kasar dan keras (Winarno, 2004).

Penambahan tahu kedelai, lama penyimpanan dan interaksi antara lama penyimpanan dengan penambahan tahu kedelai berpengaruh sangat nyata pada terhadap tekstur (kekenyalan) pada tahu susu yang disubtitusi sebagian dengan tahu kedelai.

\section{Uji Organoleptik Metode Hedonik}

Warna merupakan faktor paling penting dalam menunjukkan tingkat penerimaan konsumen terhadap suatu bahan pangan (daya tarik). Gambar 2 menunjukkan bahwa warna yang disukai panelis adalah pada perlakuan $75 \%: 25 \%$ (Tahu Susu : Tahu Kedelai) yang disimpan selama 1 dan 2 minggu $(3,6)$, sesuai dengan hasil frekuensi penilaian panelis, dimana 50\% panelis menyukai produk tersebut. Sedangkan warna yang agak disukai adalah pada perlakuan $75 \%: 25 \%$ (Tahu Susu : Tahu Kedelai) yang disimpan selama 3 minggu (3), sesuai dengan hasil frekuensi penilaian panelis, dimana $50 \%$ panelis menyukai produk tersebut. Hal ini menunjukkan bahwa daya terima panelis terhadap warna pada fermentasi tahu susu yang dihasilkan termasuk dalam kategori agak suka sampai suka. Diketahui bahwa warna pada dangke disebabkan oleh pengaruh dari warna kandungan lemak yang terdapat dalam susu hal ini sesuai dengan pendapat (Muchtadi dan Sugiyono, 1992) bahwa warna susu sapi segar putih kebiruan sampai putih kekuniangan. Warna air susu dapat berubah dari satu warna ke warna yang lain tergantung dari bangsa ternak,jenis pakan, jumlah lemak, bahan padat dan bahan pembentuk warna. Warna air susu berkisar dari putih kebiruan hingga putih keemasan.

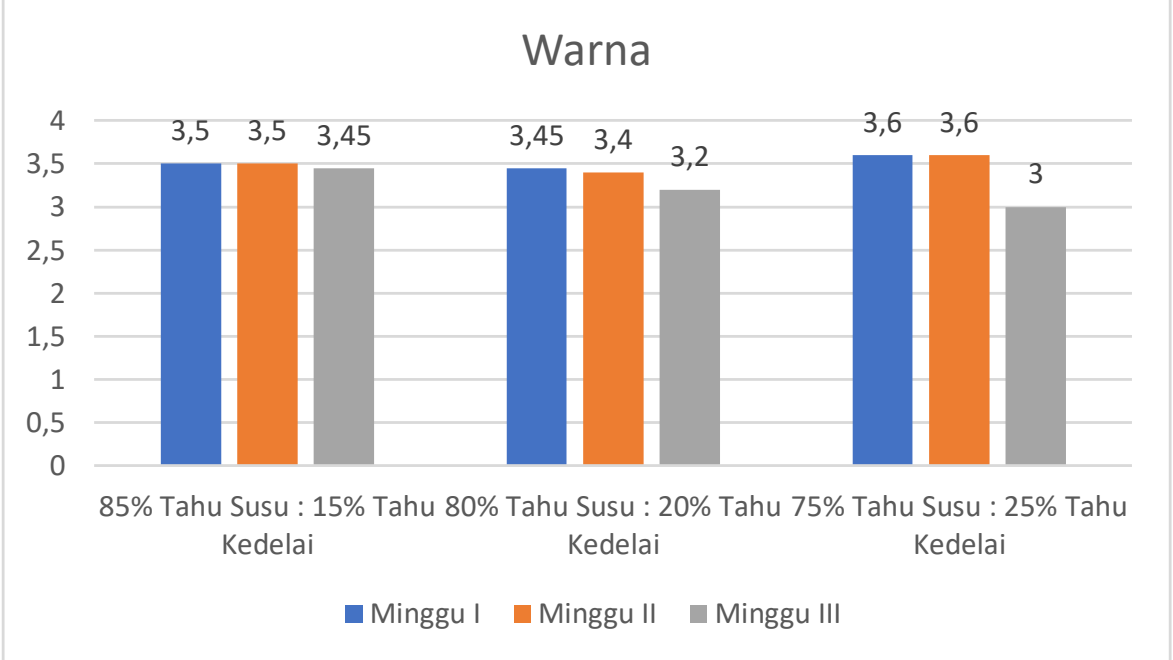

Gambar 2. Hasil Uji Organoleptik Warna Tahu Susu Fermentasi

Cita rasa bahan pangan sesungguhnya terdiri dari tiga komponen yaitu bau (aroma), rasa dan rangsangan mulut. Aroma (bau) merupakan factor penting dalam menunjukkan tingkat penerimaan konsumen dan menentukan kelezatan bahan pangan tersebut (Winarno, 2004). Hasil pengujian organoleptic yang dilakukan pada 
dua puluh panelis diperoleh skor berkisar antara 2,65-3,45. Berikut ini grafik dari hasil penilaian panelis pada aroma produk tahu susu yang difermentasi :

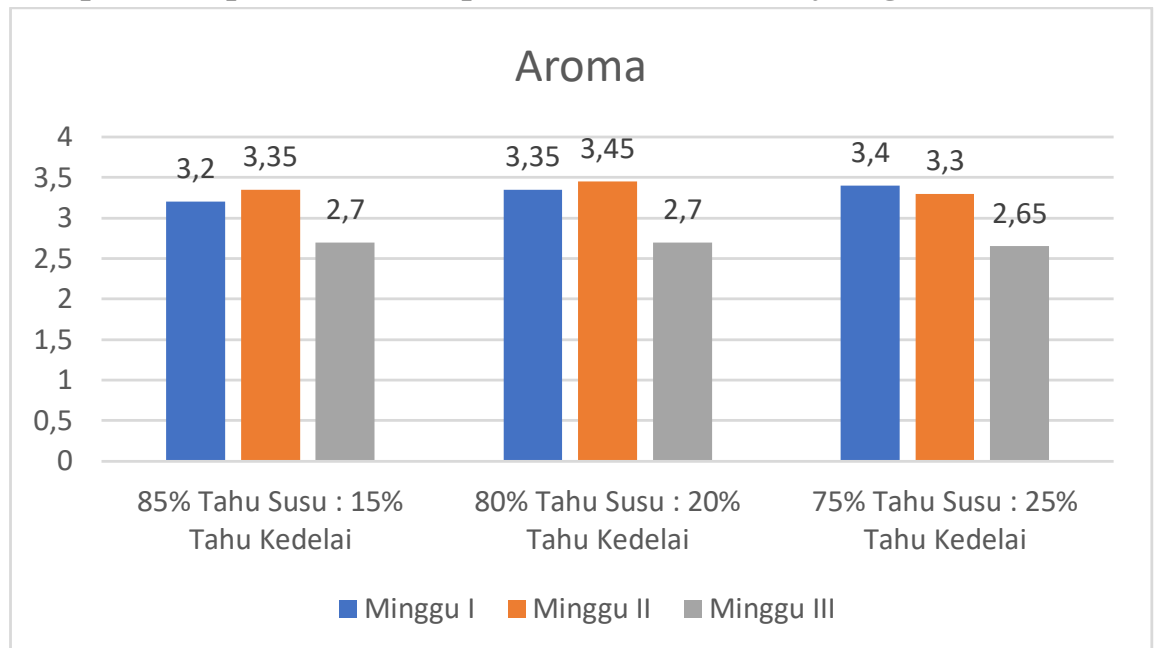

Gambar 3. Hasil Uji Organoleptik Aroma Tahu Susu Fermentasi

Gambar 3 menunjukkan bahwa aroma yang disukai panelis adalah pada perlakuan 80\%:20\% (Tahu Susu : Tahu Kedelai) yang disimpan selama 2 minggu $(3,45)$, sesuai dengan hasil frekuensi penilaian panelis, dimana $50 \%$ panelis menyukai produk tersebut. Sedangkan aroma yang tidak disukai adalah pada perlakuan 75\%:25\% (Tahu Susu : Tahu Kedelai) yang disimpan selama 3 minggu $(2,65)$, sesuai dengan hasil frekuensi penilaian panelis, dimana $50 \%$ panelis menyukai produk tersebut. Hal ini menunjukkan bahwa daya terima panelis terhadap aroma pada fermentasi tahu susu yang dihasilkan termasuk dalam kategori tidak disukai sampai suka. Hal ini disebabkan adanya bakteri Lactobacillus lactis yang menghasilkan aroma asam laktat yang kurang disenangi oleh panelis. Hal ini sesuai dengan pendapat Menurut Barlina, et al (2004) bahwa selama penyimpanan $\mathrm{pH}$ cenderung menurun. Hal ini disebabkan karena penguraian glukosa menjadi asam. Hal ini di kemukakan juga oleh Stainer, et al (1976) bahwa Penurunan nilai $\mathrm{pH}$ setelah proses fermentasi disebabkan produksi asam organik yang terus meningkat sementara produksi alkohol menurun akibat oksidasi lebih lanjut alkohol menjadi asam asam organik misalnya asam asetat

Rasa berbeda dengan bau dan lebih banyak melibatkan panca indera lidah. Rasa sangat sulit dimengertisecara tuntas oleh karena selera manusia sangat beragam (Winarno, 2002). Hasil uji organoleptic yang dilakukan pada dua puluh panelis diperoleh skor berkisar antara 2,25-2,95. Gambar 4 menunjukkan bahwa rasa yang disukai panelis adalah pada perlakuan 80\%:20\% (Tahu Susu : Tahu Kedelai) yang disimpan selama 2 minggu $(2,95)$, sesuai dengan hasil frekuensi penilaian panelis, dimana $55 \%$ panelis menyukai produk tersebut. Sedangkan rasa yang tidak disukai adalah pada perlakuan 75\%:25\% (Tahu Susu : Tahu Kedelai) yang disimpan selama 3 minggu $(2,25)$, sesuai dengan hasil frekuensi penilaian panelis, dimana $40 \%$ panelis menyukai produk tersebut. Hal ini menunjukkan bahwa daya terima panelis terhadap rasa pada fermentasi tahu susu yang dihasilkan termasuk dalam kategori tidak suka sampai agak suka pada masingmasing perlakuan selama penyimpanan. (Puspitasari et al., 2013) bahwa Interaksi lama pemanasan dan level pemberian enzim papain berpengaruh tidak nyata $(\mathrm{P}>0,05)$ terhadap kesukaan tahu susu karena pemberian enzim papain yang 
semakin tinggi dengan lama pemanasan yang relatif singkat diduga memperlambat proses penggumpalan kasein dalam susu dan rasa yang semakin pahit pada tahu susu akibat level terlalu tinggi. rasa dari danke berasal dari susu yang merupakan bahan dasar pembuatan dangke yang berasa khas dan manis. Seperti kita ketahui bahwa vitamin A,D,E dan $\mathrm{K}$ merupakan vitamin yang larut dalam lemak, pada air susu vitamin vitamin ini terdapat pada lemak susu. Rasa manis air susu karena adanya laktosa berkontribusi sekitar 40\%kalori dari air susu penuh. (Miller et al., 2000)

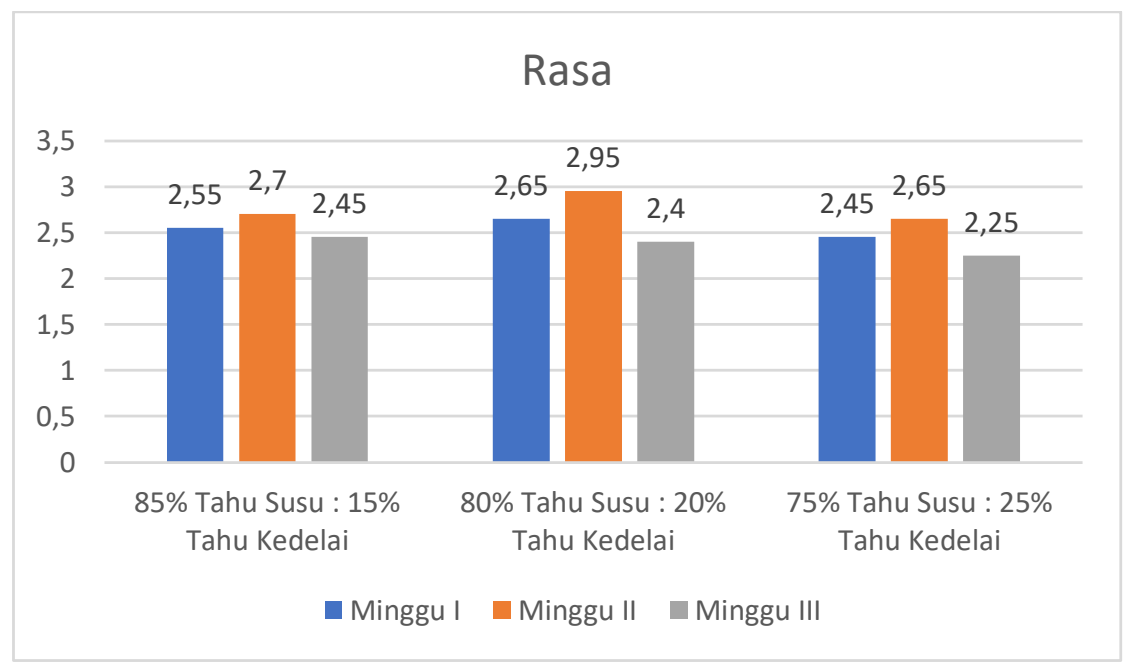

Gambar 4. Hasil Uji Organoleptik Rasa Tahu Susu Fermentasi

Tekstur merupakan salah satu sifat fisik dari bahan pangan yang penting. Hal ini berhubungan dengan rasa pada waktu mengunyah bahan pangan tersebut. Hasil uji organoleptik yang dilakukan pada dua puluh panelis diperoleh skor berkisar antara 2,65-3,3. Berikut ini grafik dari hasil penilaian panelis pada tekstur produk tahu susu yang difermentasi :

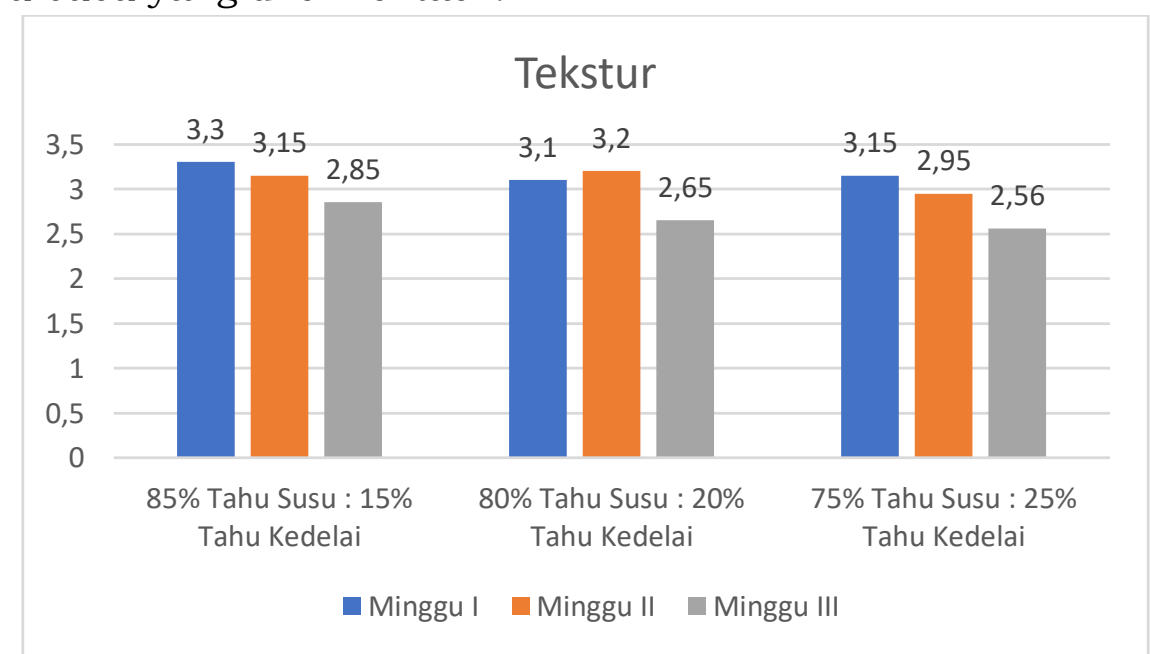

Gambar 5. Hasil Uji Organoleptik Tekstur Tahu Susu Fermentasi

Gambar 5 menunjukkan bahwa tekstur yang disukai panelis adalah pada perlakuan 85\%:15\% (Tahu Susu : Tahu Kedelai) yang disimpan selama 1 minggu $(3,3)$, sesuai dengan hasil frekuensi penilaian panelis, dimana $50 \%$ panelis menyukai produk tersebut. Sedangkan tekstur yang tidak disukai adalah pada perlakuan 75\%:25\% (Tahu Susu : Tahu Kedelai) yang disimpan selama 3 minggu $(2,65)$, sesuai dengan hasil frekuensi penilaian panelis, dimana $70 \%$ panelis menyukai produk 
tersebut. Hal ini menunjukkan bahwa daya terima panelis terhadap tekstur pada fermentasi tahu susu yang dihasilkan termasuk dalam kategori tidak suka sampai agak suka dari semua perlakuan selama penyimpanan. Hal ini karena perbedaan sifat fisik protein tahu susu sapi dengan protein tahu kedelai. Menurut penelitian (Yuniwati et al.,2008) banyaknya produk yang dihasilkan disebabkan karena hasil yang diperoleh banyak mengandung air yang sulit dipisahkan dari produk padatan karena proses penggumpalan yang kurang sempurna, maka produk yang dihasilkan mempunyai tekstur yang tidak bagus (lembek), selain itu apabila penambahan enzim papain optimal, maka produk yang dihasilakan tidak begitu besar tetapi kadar airnya kecil karena pengendapan lebih sempurna sehingga air mudah dipisahkan dari padatan yang diinginkan maka tekstur lebih bagus (kenyal).

\section{KESIMPULAN}

Berdasarkan dari hasil penelitian dapat disimpulkan bahwa perlakuan terbaik fermentasi tahu susu yang disubtitusi dengan tahu kedelai yaitu perlakuan tahu susu sapi $85 \%$ dan tahu susu kedelai $15 \%$ baik dari segi kekenyalan maupun tingkat kesukaan (aroma, warna, rasa dan tekstur.

\section{DAFTAR PUSTAKA}

Arum, R. H., B. Satiawihardja, \& H. D. Kusumaningrum., 2014. Aktivitas antibakteri getah pepaya kering terhadap Staphylococcus aureus pada dangke. Jurnal Teknologi dan Industri Pangan, Vol 25: 65-71.

Buckle, K.A., R.A. Edwars G.H. Flect M. Wooton 1987., Ilmu Pangan. Penerjemah Punomo, H. dan Adiono. Universitas Indonesia Press, Jakarta.

Djide, 1991. Analisis mikrobiologi dangke asal Enrekang. Laporan Penelitian. Fakultas MIPA, Universitas Hasanuddin, Makassar.

Fennema, O.W., 1985. Principle of Food Science, Food Chemistry, 2nd (ed). Marcel Dekker Inc, New York

Fitrah, I., 2012. Studi Tingkat Higiene Dan Cemaran Bakteri Salmonella sp Pada Pembuatan Dangke Susu Sapi Di Kecamatan Cendana Kabupaten Enrekang. Universitas Hasanuddin, Makassar.

Geantaresa, E., Supriyanti, F. M. T., 2010. Pemanfaatan Ekstrak Kasar Papain Sebagai Koagulan Pada Pembuatan Keju Cottage Menggunakan Bakteri. Jurnal Sains dan Teknologi Kimia, Vol 1 (1) : 38-43.

Gemy, N. H., Nur, I., Ahmad, R. R., 2014. Pemanfaatan Susu Skim Sebagai Bahan Dasar Dalam Pembuatan Produk Olahan Makanan Tradisioanl Dangke Dengan Bantuan Bakteri Asam Laktat. JF FIK UINAM, Vol 2 (2).

Jufri, Imam., 2016. Pengaruh Level Getah Pepaya Kering dan Suhu Pemanasan

Terhadap Kualitas Kimia Dangke. Skripsi Fakultas Peternakan Universitas Hasanuddin, Makassar.

Kalie, 1990. Tanaman Pepaya. Penebar Swadaya, Jakarta

Malaka, R., 2010. Pengantar Teknologi Susu. Masagena Press, Makassar

Malaka, R., Baco, S., Prahesti, K. I., 2015. Karakteristik dan Mekanisme

Gelatinasi Curd Dangke melalui Analisis Fisiko Kimia dan Mikrostruktur.

Buletin Ilmu \& Teknologi Peternakan 
Marzoeki, A.A., M. A Hafid, M. Jufri, Amir dan Madjid., 2003. Peningkatan mutu dangke. Laporan Penelitian. Balai Penelitian Kimia Departemen Perindustrian, Makassar.

Ming, C.C., A. Bono., D. Krisnaiah dan T.S. Han., 2002. Effects of ionic and nonionik surfactants on papain activity. Borneo Science, Vol 12: 71-77.

Muchtadi, D., N.S. Palupi dan M. Astawan., 1992. Enzim dalam Industri Pangan.

Departemen Pendidikan dan Kebudayaan Direktorat Jenderal Pendidikan Tinggi Pusat Antar Unversitas Pangan dan Gizi Institut Pertanian Bogor, Bogor.

Muchtadi, TR dan Sugiyono., 1992. Ilmu Pengetahuan Bahan Pangan. Bogor: IPB Mustikawati, A., 2001. Pengaruh Pemberian Bahan Penggumpal Dan Suhu Pemasakan Yang Berbeda Terhadap Produksi Dangke Susu Sapi. Jurusan Peternakan, Universitas 45, Makassar

Sarwono, B., dan Saragih, Y. P., 2001. Membuat Aneka Tahu. Penebar Swadaya, Jakarta.

Sri Usmiati dan Risfaheri., 2012. Pengembangan Dadih sebagai Pangan Fungsional Probiotik Asli dari Sumatra Barat. Jurnal Litbang Pertanian, Vol 32 (1) : 20-29

Pardede, B. E., Adhitiyawarman, \& S. Arreneuz., 2013. Pemanfaatan Enzim Papain

Dari Getah Buah Pepaya (Carica papaya L) Dalam Pembuatan Keju Cottage Menggunakan Bakteri Lactobacillus bulgaricus. Jurnal Kimia Khatulistiwa, Vol 2(3).

Winarno, F.G., 1995. Enzim Pangan. Gramedia Pustaka Utama, Jakarta.

Winarno, F.G., 2004. Kimia Pangan dan Gizi. Gramedia Pustaka Utama, Jakarta

Yuniwati, M., Yusran dan Rahmadany. 2008. Pemanfaatan Enzim Papain Sebagai

Penggumpal Dalam Pembuatan Dangke. Seminar Nasional Aplikasi Sains dan Teknologi. Yogyakarta. 